\title{
ELECTROPHEROTYPES AND SUBGROUPS OF GROUP A ROtaViRUSes Circulating among DiaRrhoeic ChILDREN IN KANO, Nigeria
}

\author{
${ }^{1}$ A. A Dzikwi, ${ }^{1}$ J. U. Umoh, ${ }^{1}$ J. K. P. Kwaga, ${ }^{2}$ A. A. Ahmad, ${ }^{3}$ M. deBeer and ${ }^{3}$ A. D Steele \\ ${ }^{1}$ Department of Veterinary Public Health and Preventive Medicine, Ahmadu Bello University, Zaria, Nigeria \\ ${ }^{2}$ Department of Microbiology, Faculty of Science, Ahmadu Bello University, Zaria, Nigeria \\ ${ }^{3} \mathrm{MRC} / \mathrm{MEDUNSA}$ Diarrheal Pathogens Research Unit, Medical University of South Africa, Pretoria, South Africa \\ Reprint requests to: Dr A. A. Dzikwi, Department of Veterinary Public Health and Preventive Medicine, Ahmadu \\ Bello University, Zaria, Nigeria.E mail: asabezik@yahoo.com
}

\begin{abstract}
Background: It is estimated that about 600000 children die annually as a result of severe dehydrating diarrhea caused by rotaviruses. The virus is a double stranded RNA (dsRNA) virus with 11 segments. Group A rotaviruses show a characteristic 4-2-3-2 pattern following electrophoresis. The VP6 subgroups, I and II exist. This work was carried out to study the prevalence of rotavirus infection among children 0-5 years with diarrhea in Kano, and to determine the circulating subgroups and electropherotypes and of the rotavirus isolates.

Methods: Two hundred and eighteen stool specimens from children 0-60 months (198 diarrheic and 20 non-diarrheic) were collected from different hospitals and health care centers in Kano and subjected to group $A$ rotavirus enzyme linked immunosorbent assay (ELISA) to determine presence of group $A$ rotavirus, subgroup ELISA to determine the VP6 subgroups and polyacrylamide gel electrophoresis (PAGE) to determine the electropherotypes present.

Results: The long electropherotypes (47.05\%) of four variations dominated over the short electropherotype (17.64\%). About $11.76 \%$ of the isolates were of mixed infection. Dominance of subgroup II (45\%) over subgroup I (25\%), and the presence of both subgroups I and II (10\%) and neither subgroup I nor II (15\%) was observed in this study.

Conclusion: Information on the genomic diversity of the RNA electropherotypes in this region, Kano, is reported in this study.
\end{abstract}

Key words: Electropherotypes, Subgroups, Group A, Rotavirus, Nigeria

\begin{abstract}
Résumé
Fond: On l'estime qu'environ 600.000 enfants meurent annuellement en raison de la diarrhée de déshydratation grave provoquée par des rotaviruses. Le virus est un virus bicaténaire d'ARN (dsRNA) avec 11 segments. Groupez l'exposition de rotaviruses d'A un modèle 4-2-3-2 caractéristique après l'électrophorèse. Les sous-groupes VP6, I'I et I'Il existent. Ces travaux ont été menés à bien pour étudier la prédominance de l'infection de rotavirus parmi des enfants 0-5 ans avec la diarrhée dans Kano, et pour déterminer les sous-groupes et les electropherotypes de circulation et des isolats de rotavirus.

Méthodes: Deux cents et dix-huit spécimens de selles des enfants 0-60 mois (198 diarrhoeic et 20 nondiarrhoeic) ont été rassemblés de différents hôpitaux et centres de santé dans Kano et soumis au groupe que l'enzyme de rotavirus d'A a lié l'analyse d'immunosorbant (ELISA) pour déterminer la présence du rotavirus du groupe A, ELISA de sous-groupe pour déterminer les sous-groupes VP6 et l'électrophorèse de gel de polyacrylamide (PAGE) pour déterminer les electropherotypes actuels.
\end{abstract}


Résultats: Les longs electropherotypes (47.05\%) de quatre variations ont dominé sur l'electropherotype court (17.64\%). Environ $11.76 \%$ des isolats étaient de l'infection mélangée. On n'a observé la dominance du sous-groupe d'excédent du sous-groupe II (45\%) I (25\%), et la présence des deux sousgroupes I et II (10\%) et ni sous-groupe I ni II (15\%) dans cette étude.

Conclusion: L'information sur la diversité genomic des electropherotypes d'ARN dans cette région, Kano, est rapportée dans cette étude.

\section{Mots clés: Electropherotypes, sous-groupes, groupent A, Rotavirus, Nigéria}

\section{Introduction}

Rotavirus is the single most important cause of severe diarrheal illness in infants and young children in both developing and developed countries. ${ }^{1}$ The virus also infects the young of other mammals and avians. $^{2}$ It composes a genus in the family Reoviridae and is a medium sized (70nm) and non enveloped virus. ${ }^{3}$ A conservative estimate of 600,000 children die because of infection with this virus, most of this figure being from Asia and Africa. The most cost effective means of intervention is vaccination; therefore the epidemiology of this disease is important to ensure proper intervention with regards to the circulating strains in different regions of the world. There also exist many reports of emerging reassortants. 4

In Nigeria, reports on the prevalence and characterization of the virus in young children exist. . $^{6}$ ${ }^{9}$ VP6 is the most abundant protein. ${ }^{10}$ It is stable and has conserved epitopes which makes it a major target in diagnostic assays. ${ }^{11}$ Furthermore, it is highly immunogenic and antigenic therefore it may be important in protective immunity. ${ }^{12}$ The objective of this study was to provide additional information from an area not previously.

\section{Materials and Methods}

\section{Collection and handling of specimens}

A total of 218 fresh faecal specimens were collected from 198 diarrhoiec children and 20 non-diarrhoiec controls 0-5 years of age in sterile bottles. Information was obtained on the ages and sexes of the children. Six hospitals within Kano metropolis namely Hasiya Bayero Paediatrics Hospital, Classic Clinics, Sir Sanusi Specialist Hospital, Assumpta Clinics, International Clinics and Abdullahi Wase Specialist Hospital served as collection centres. These hospitals were selected on satisfaction of the following criteria: Consent of the authorities, availability of a paediatrics unit and a reasonable number of patients visiting per day (approximately $50)$. The specimens were appropriately labeled and stored at $-20^{\circ} \mathrm{C}$ at the collection centres prior to transportation in a cold box to MRC/MEDUNSA where they were analysed.

\section{Group A ELISA}

A $10-20 \%$ suspension of each faecal specimen was made using Bartex water and screened for group $A$ rotavirus by double sandwich ELISA using commercially available DAKO kits (IDEIA $^{\text {TM }}$, Dako Cambridgeshire, UK) according to manufacturer's instructions. Results were read spectrophotometrically at $450 \mathrm{~nm}$.

\section{PAGE}

Only ELISA positive specimens were subjected to PAGE to confirm the presence of Group A rotaviruses and to determine the circulating electropherotypes. Viral RNAs were extracted as described. ${ }^{13}$ Briefly, $50 \mu \mathrm{l}$ prewarmed sodium acetate (NaAc) containing $10 \%$ sodium dodecyl sulphate (SDS) was added to approximately $400 \mu \mathrm{l}$ stool suspension, incubated at $37^{\circ} \mathrm{C}$ in a water bath after which 500ul phenol/chloroform (1:1) was added to release the RNA. These were mixed in a vortex machine for 1 minute and incubated at $56^{\circ} \mathrm{C}$ for 15 minutes in a water bath. Air pressure was released by quickly opening and closing back the Eppendorf tube. The contents were mixed and centrifuged at $12,000 \mathrm{rpm}$ for 3 minutes to sediment. The upper aqueous phase was collected in a clean Eppendorf tube to which about $40 \mu \mathrm{l} 3 \mathrm{M} \mathrm{NaAc}$ and $1 \mathrm{ml}$ absolute ethanol were added, gently mixed and incubated overnight at $20^{\circ} \mathrm{C}$. The RNAs pellets left in the tube, after being centrifuged and the supernatant poured off were airdried. PAGE was carried out using the discontinuous buffer system as described elsewhere. ${ }^{14}$ Slab gels $(10 \%)$ and $3 \%$ spacer gels were used. About $30 \mu$ l of each sample was loaded onto the gels and electrophoresis carried out at $100 \mathrm{v}$ for 18 hours at room temperature. Silver staining of the gels was done as described elsewhere. ${ }^{15}$

\section{VP6 Subgroup ELISA}

The VP6 subgroups of rotavirus strains were determined using the VP6 monoclonal antibodies. ${ }^{16}$, 17 An ELISA protocol developed by MRC/MEDUNSA Diarrheal Pathogens Unit was used as described below. Microtitre plates were coated with rabbit anti-human rotavirus overnight at $4^{\circ} \mathrm{C}$ and repeatedly washed six times in phosphate buffered saline/tween 20 (PBS/T). About $50 \mu$ l stool suspension was added, followed by $100 \mu \mathrm{l}$ PBS/T/EDTA into three consecutive wells and incubated at $4^{\circ} \mathrm{C}$ overnight. 
Positive and negative controls consisted of standard rotavirus strain and distilled water respectively. $A$ 1:5000 dilution of rotavirus Group antigen (A3M4),16 Subgroup I (mouse \# 255/60/125/14) and Subgroup II (mouse \#631/9/104/56)17 monoclonal antibodies were done in PBS/T/Bovine Serum Albumen (BSA). $\mathrm{PBS} / \mathrm{T} / \mathrm{BSA}$ was prepared by dissolving $5 \mathrm{~g}$ BSA in 1 litre $\mathrm{PBS} / \mathrm{T}$ at $\mathrm{pH} 7.2$ stored at $-20^{\circ} \mathrm{C}$. The monoclonal antibody $(10 \mu \mathrm{l})$ was diluted in $10 \mathrm{ml}$ PBS/T/BSA and $100 \mu \mathrm{l}$ dispensed into every third row. Horseradish peroxidase conjugate obtained (Zymed, San Francisco, USA) was used at a dilution of 1:1000 with PBS/T/BSA to detect activity. About $100 \mu \mathrm{l}$ was dispensed per plate and incubated at $37{ }^{\circ} \mathrm{C}$ for 2 hours. The plates were washed in PBS/T. To each well, $100 \mu$ of a mixture of hydrogen peroxide and 3, 3'5, 5'-tetramethylbenzidine (TMB) was added and plates incubated for 10 minutes in the dark. The reaction was read visually then $5 \%$ sulphuric acid was added to stop the reaction. The plates were read spectrophotometrically at $450 \mathrm{~nm}$ and the optical densities determined.

\section{Results}

\section{Group A ELISA}

Twenty seven (12.4\%) specimens were positive out of 218 specimens screened. Of the positive specimens, one came from a non diarrhoeic child. Children 0-12 months of age had the highest rate of infection and the mode of $18.57 \%$ came from the $7-12$ months age group.

\section{PAGE}

Of the 27 ELISA positive specimens, 22 were analysed by PAGE. The remaining five were not tested. Seventeen yielded electropherotype patterns while five did not yield enough RNA bands on the gel to permit their electropherotype determination. Nine (40.9\%) exhibited long electropherotypes of four variations while three $(13.6 \%)$ exhibited short electropherotypes. Two samples (9.1\%) were of mixed infection with more than 11 segments each. The electropherotypes of the remaining three (13.6\%) could not be determined. Figures 1 and 2 show the migration patterns on polyacrylamide gel.

\section{VP6 Subgroups}

Five $(22.72 \%)$ of the ELISA-positive samples belonged to subgroup I, nine (40.90\%) belonged to subgroup II. Two (9.09\%) belonged to subgroup $\mathrm{I} / \mathrm{II}$ and coincidentally both of them appeared faint on gel. Three $(13.63 \%)$ of the samples belonged to neither subgroup I nor II. The subgroup of three others could not be determined (Table 1). L1 and S1 electropherotypes exhibited subgroup I specificity while L2 were of subgroup II specificity. The only L4 belonged to subgroup I/II (Table 1).
Figure 1. RNA migration patterns of some Nigerian Group A rotaviruses detected in Kano showing different variations of long electropherotype, short electropherotype and mixed electropherotype [The migration is from top to bottom. Lanes: B (L4), H (L2), J (S1), and $L(M)$ ]

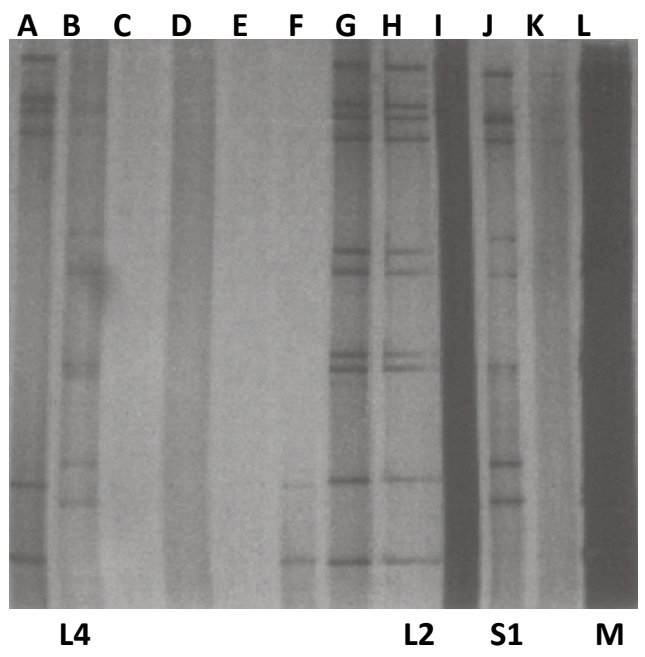

Figure 2. RNA migration patterns of some Nigerian Group A rotaviruses detected in Kano showing different variations of long electropherotypes [Migration is from top to bottom. Lanes 2(L3), 7 (L1) and 9 (L2)]

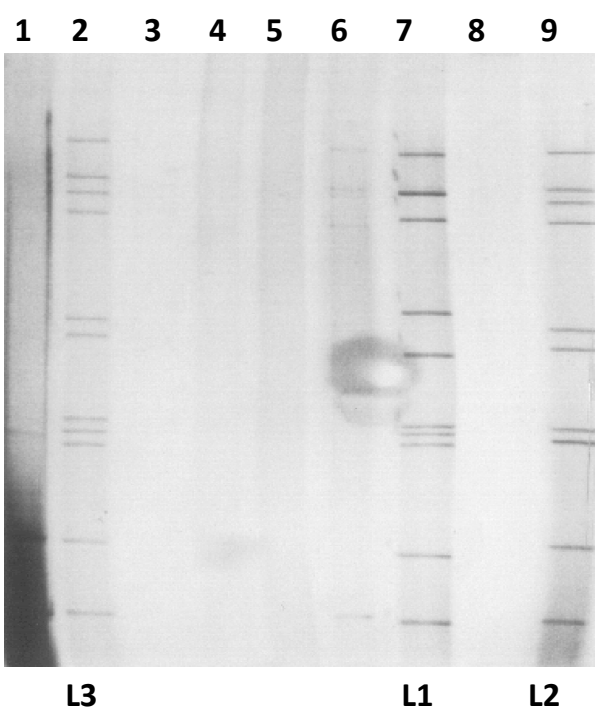

Table 1: Frequency of electropherotypes and subgroups of Rotavirus circulating among diarrhoeic children in Kano

\begin{tabular}{l|l}
\hline Electropherotype & No. (\%) Subgroup \\
\hline L1 & $2(9.09) \mathrm{I}$ \\
L2 & $5(22.73) \mathrm{II}$ \\
L3 & $1(4.55) \mathrm{nd}$ \\
L4 & $1(4.55) \mathrm{I} / \mathrm{II}$ \\
S1 & $3(13.64) \mathrm{I}$ \\
Mixed & $2(9.09) \mathrm{II}$ and I/II \\
Not determined & $3(13.64) \mathrm{II} / \mathrm{I}$ and II \\
(faint/incomplete) & \\
Negative & $5(22.73) \mathrm{II}, \mathrm{nd}$ \\
\hline
\end{tabular}


The long profile was more common among males and among the age-group 7-12 months, while the short profile was more common among females and the 0 -
6 months age-group. The mixed electropherotypes occurred only among females of not more than 12 months (Table 2).

Table 2. Distribution of electropherotypes in relation to sex and age among diarrhoeic children in Kano

\begin{tabular}{lllllll}
\hline $\begin{array}{l}\text { RNA } \\
\text { Profile }\end{array}$ & $\begin{array}{l}\text { Sex } \\
\text { Male }\end{array}$ & Female & $\begin{array}{l}\text { Age } \\
\text { (Months) }\end{array}$ & & \\
\cline { 3 - 6 } & & & $\mathbf{0 - 6}$ & $\mathbf{7 - 1 2}$ & $\mathbf{1 3 - 1 7}$ & $>\mathbf{1 7}$ \\
\hline Long & $5(55.60)^{*}$ & $4(44.40)$ & $1(11.11)$ & $4(44.44)$ & $2(22.22)$ & $2(22.22)$ \\
Short & $1(33.33)$ & $2(77.77)$ & $2(66.66)$ & $1(33.33)$ & - & - \\
Mixed & $0(0.00)$ & $2(100)$ & $1(50)$ & $1(50)$ & - & - \\
Nd & $1(33.33)$ & $2(66.7)$ & - & $2(66.66)$ & $1(33.33)$ & - \\
Negative & $3(60 \%)$ & $2(40)$ & $1(20)$ & $3(60)$ & - & $1(20)$ \\
\hline
\end{tabular}

Nd: not determined; * Percentages are in parenthesis

\section{Discussion}

This work reports the dominance of the long electropherotypes of rotavirus. This is similar to observations that the long electropherotype of rotavirus dominates in many African Countries ${ }^{18}$ and in Nigeria. ${ }^{8}$ Although the typical group A pattern is the 4-2-3-2, atypical ones may arise due to shift, drift or rearrangement. ${ }^{11}$ All the group A ELISA positive isolates gave the characteristic pattern. However, there was a lone short type (S1) reported in this work. Electropherotypes provide information on genetic diversity of rotavirus, heterogeneity of circulating rotaviruses and are useful in tracing spread through a population. ${ }^{10}$ Viruses of same serotype can exhibit different electropherotypes and those of same electropherotypes, different serotypes. ${ }^{10,19}$ In this study, $23 \%$ of the ELISA positive specimens exhibited no bands on PAGE while $14 \%$ were of the short type. There is a report of a similar finding of $26 \%$ and $10 \%$ of the PAGE negative and short types respectively (personal communication). The absence of the band could be due to too little RNA or its destruction during extraction by phenol/chloroform. ${ }^{8}$ The implication of mixed infection is that reassortants are likely to emerge since there is simultaneous infection of an individual with different isolates. ${ }^{20}$ The short and mixed electropherotypes were observed in children 0-12 months of age. At this point it is not clear why this age group alone in this study exhibited these electropherotypes. It may be necessary for more studies to explain this occurrence. The short electropherotype were of SI as expected. The long electropherotypes even though were expected to be SII exhibited SI, SII and others that could not be determined.

VP6 subgroup specificity testing by ELISA yielded a dominance of subgroup II (41\%) over subgroup I (23\%). This agrees with the findings in South Africa, Tunisia, and Nigeria. ${ }^{4,8,9,21}$ Two (10\%) of the samples reacted to both subgroup I and subgroup II monoclonal antibodies while three (14\%) reacted with the group but neither subgroup I nor II monoclonal antibodies. A possible explanation for this may be that the stool specimens probably contained low level of the virus. ${ }^{21}$ These two specimens appeared very faint on PAGE, which indicates low RNA level. This work shows evidence of great diversity of rotavirus strains circulating at the same time within a single metropolis. Kano is heavily populated and suggests rich variety of strains within this type of locations. This study provides information on the genomic diversity of RNA electropherotypes even though a clear-cut pattern for subgroups and electropherotypes did not exist.

\section{Acknowledgements}

The authors acknowledge WHO and MRC/MEDUNSA for sponsoring this work. The work was done during the WHO African Rotavirus Workshop held MEDUNSA in 2002. The authorities and staff of the hospitals in Nigeria where the specimens were obtained are also acknowledged.

\section{References}

1. Parashar UD, Holman RC, Clarke MJ, Breese JS, Glass RI. Hospitalisations associated with rotavirus diarrhea in the United States, 1993 through 1995: surveillance based on the new ICD-9-CM rotavirus specific diagnostic code. J Infect Dis. 1998; 177:13-17.

2. Flewett TH, Woode GN. The Rotaviruses: Brief review. Arch Virol. 1978; 57:1-23.

3. Hoshino $Y$, Kapikian AZ. Rotavirus serotypes: classification and importance in epidemiology, immunity, and vaccine development. J Health Popul Nutr. 2000; 18:5-14.

4. Trabelsi A, Peenze I, Pager C, Jeddi M, Steele AD. 
Distribution of rotavirus VP7 serotypes and VP4 genotypes circulating in Sousse, Tunisia from 1995 to 1999: Emergence of natural human reassortants. J Clin Microbiol. 2000; 38:34153419.

5. Varshney B, Jagannath MR, Vethanayagam RR, et al. Prevalence of, and antigenic variation in serotype $\mathrm{G} 10$ rotaviruses and the detection of serotypes G3 strains in diarrhoeic calves: implications for the origins of G10P11 or P11 type reassortant asymptomatic strains in newborn children in India. Arch Virol. 2002; 147:143-146.

6. Adah MI, Rohwedder A, Olaleye OD, Werchau H. Further characterization of field strains of rotavirus from Nigeria VP4 Genotype P6 most frequently identified among symptomatically infected children. J Trop Pediatr. 1997; 43:267274.

7. Adah MI, Wade A, Taniguchi K. Molecular epidemiology of rotavirus in Nigeria: Detection of unusual strains with G2P [6] and G8P [1] specificities. J Clin Microbiol. 2001; 39:39693975.

8. Pennap G, Peenze I, de Beer $M$, et al. VP6 subgroup and VP7 serotype of human rotavirus in zaria, Northern Nigeria. J Trop Pediatr. 2000; 46:344-347.

9. Audu R, Omilabu SA, de Beer M, Peenze I, Steele AD. Diversity of human rotavirus VP6, VP7 and VP4 in Lagos State, Nigeria. J Health Popul Nutr. 2002; 20:59-64.

10. Kapikian AZ, Hoshino $Y$, Chanock RM. Rotaviruses In: Fields BN, Knippe D M, Howley PM et al. (Eds). Virology. Vol. 2, 4th edition. Lippincott Williams and Wilkins, Philadelphia. $2001 \mathrm{Pp}$ 1787-1833.

11. Estes MK. Rotaviruses and their replication In: Fields BN, Knippe DM, Howley PM et al. (Eds). Virology. Vol. 2, 4th edition. Lippincott Williams and Wilkins, Philadelphia. 2001 Pp 1747-1785.

12. Gorziglia MI, Collins PL. Intracellular amplification and expression of a synthetic analogue of rotavirus genomic RNA bearing a foreign marker gene. Mapping cis-acting nucleotide in the 3? non- coding region. Proc Natl Acad Sci USA. 1992; 89:5784-5788.

13. Herring AJ, Inglis NT, Ojeh CK, Snodgrass DR, Menzies JD. Rapid diagnosis of rotavirus infection by direct detection of viral nucleic acid in silver stained polyacrylamide gels. J Clin Microbiol. 1982; 16:473-477.

14. Laemmli UK. Cleavage of structural proteins during the assembly of head of bacteriophage T4. Nature. 1970; 227:680-685.

15. Steele AD, Alexander JJ. The relative frequency of subgroup I and II rotaviruses in South Africa. J Med Virol. 1988; 24:321-327.

16. Beards GM, Campbell AD, Cottrell NR, et al. Enzyme-linked immunosrbent assay based on polyclonal and monoclonal antibodies for rotavirus detection. J Clin Microbiol. 1984; 19:248-254.

17. Greenberg H, McAuliffe V, Valdesuso J, et al. Serological analysis of the subgroup protein of rotavirus, using monoclonal antibodies. Infect Immun. 1983; 39:91-99.

18. Cunliffe NA, Kilgore PE, Bresee JS, et al. Epidemiology of rotavirus diarrhea in Africa: a review to assess the need for rotavirus immunization. Bull World Health Organ. 1998; 76:525-37.

19. Beards GM. Polymorphism of genomic RNAs within rotavirus serotypes and subgroups. Arch Virol. 1982; 74:65-70.

20. Steele AD, Bos P, Gove E, Meewes PJ, Alexander JJ. Variation in genomic RNA rotavirus electropherotype isolated from white and black infants in Southern Africa. S Afr J Sci. 1988; 84:574-576.

21. Sebata $T$, Steele AD. Atypical rotavirus identified from young children with diarrhoea in South Africa. J Health Popul Nutr. 2001; 19:1-5. 